\title{
Hate Speech and Blasphemy on Social Media in Indonesia: Forensic Linguistic Studies
}

\author{
Agus Syahid $^{1 *}$ Dadang Sudana ${ }^{2,}$ Andika Dutha Bachari ${ }^{3}$ \\ 1,2,3 Linguistics, Postgraduate School, Universitas Pendidikan Indonesia, Bandung, Indonesia \\ *Corresponding author. Email: deragus@gmail.com
}

\begin{abstract}
The development of technology and information as well as the very rapid use of social media today makes it easy for someone to write a status or comment about what he thinks. Not infrequently, someone's status or speech on social media which is considered to contain elements of language crime can have legal implications if other peoples feel insulted by the utterances. This study aims to analyze hate speech that contains elements of blasphemy on social media and the legal impact of these utterances. The research method used is qualitative with a forensic linguistic approach. The data source is taken from the decision of the Medan District Court with decision number 931/Pid.Sus/2019/PN.Mdn has permanent legal force. Based on data analysis, the results of this study are: (1) the expressive speech act committed by the defendant contains utterances of hatred or contempt for a particular religion and (2) based on the appraisal system analysis, the defendant's utterance of hatred towards religion was evident from the use of language which was reflected in her attitude. The results of this study are that there is a criminal act intentionally showing hatred towards certain individuals and or groups of people based on religion through social media based on Article 28 paragraph (2) of Law No.19 of 2016 about the changes of the Law Number 11 of 2008 on Information and Electronic Transactions (ITE) in terms of speech act theory and appraisal system.
\end{abstract}

Keywords: forensic linguistics, blasphemy, speech act analysis, appraisal system.

\section{INTRODUCTION}

Etymologically the word "Tindak Pidana Penistaan Agama" comes from the words "tindak pidana" and "penistaan agama". The term "tindak pidana" is a technical juridical term from the Dutch language, namely "Strafbaar feit". In his book entitled Azas-Azas Hukum Pidana, Moeljatno [1] says that Strafbaar feit is a behaviour (handling) that is threatened with criminality, which is against the law, related to mistakes made by people who are capable of being responsible. While the term "Penistaan Agama" consists of the words "penistaan" and "agama". When viewed from the morphological process, the word "penistaan" is formed from the word "nista" which is given the confix pe-, -an so that it forms the noun "penistaan". The word "nista" itself in the online page of Kamus Besar Bahasa Indonesia (KBBI) [2] means contempt, unpleasant to hear, reproach and stain, so "penistaan" can be interpreted as humiliation, harassment, or blasphemy. Meanwhile, according to the KBBI online "agama" is a teaching, a system that regulates faith (belief) and worship of God Almighty as well as rules relating to the relationship between humans and humans and their environment. So it can be said that "penistaan agama" (blasphemy) is an act of insulting, harassing, or tarnishing something that is believed by a person or group of people through actions, speech, or writing. Based on the description above, a person who can be charged with blasphemy is a person who is capable of being responsible, namely: mature and sane. The act of blasphemy is carried out intentionally either through actions, speech, or writing to demean or insult a religion or belief of another person by conveying it to the public.

Legal rules regarding the crime of blasphemy have been regulated in the Criminal Code (KUHP) and the Information and Electronic Transactions Law (ITE Law). The criminal act of blasphemy is carried out directly without going through electronic media such as in posters, banners, billboards, oral utterances, and so on are regulated in Article 156 of KUHP with the provisions of lex generalis, while criminal acts are carried out using electronic media such as social media, websites, blogs, e-mails, and so on are regulated in the ITE Law with the provisions of lex specialist [3]. So 
that to be able to establish a legal fact related to violations of the ITE Law several expert views are needed including; (1) criminal law expert, to see whether an action taken fulfils a criminal element or not, (2) ITE expert, to see whether a legal event related to electronic information and transactions has occurred, (3) linguist expert, to see if the information contained in the form of language contains anything (such as blasphemy, threats, fake news, hate speech, incitement, slander, etc.) as well as other experts related to the violation of the law. In this study, hate speech containing elements of blasphemy is carried out through social media Facebook, so the articles that are suitable to be applied are Article 28 paragraph (2) Jo. Article 45A paragraph (2) of Law No.19 of 2016 about the changes of Law Number 11 of 2008 on ITE [4] which regulates the prohibition of making hate speech based on ethnicity, religion, race, and intergroup (SARA) through electronic media.

The ITE Law Article 28 paragraph (2) No.19 of 2016 about the changes of the Law Number 11 of 2008 on ITE [4] states that "Everyone intentionally and without rights disseminates information aimed at creating a sense of hatred or hostility towards certain individuals and/or community groups based on ethnicity, religion, race, and intergroup (SARA)". Next, the criminal provisions are regulated in Article 45A paragraph (2) of Law Number 19 of 2016 about the changes of the Law Number 11 of 2008 which reads "Anyone who intentionally and without rights disseminates information aimed at causing hatred or hostility to individuals and/or groups. certain people based on ethnicity, religion, race, and intergroup (SARA) as referred to in Article 28 paragraph (2) shall be punished with imprisonment for a maximum of 6 (six) years and/or a fine of a maximum of $\mathrm{Rp}$. 1,000,000,000.00 (one billion rupiah)". The two articles, namely Article 28 paragraph (2) and Article 45A paragraph (2) explain that anyone who intentionally disseminates information intended to cause hatred or hostility to certain individuals and/or community groups based on ethnicity, religion, race, and Intergroup relations (SARA) through electronic media so that it can be accessed by the public is an act against the law and can be charged with imprisonment for a maximum of six years and/or a fine of a maximum of one billion rupiahs. Blasphemy is one of the unlawful acts described in the article above.

In Indonesia, there are several cases of hate speech containing elements of blasphemy carried out through social media. On the website of Direktori Putusan Mahkamah Agung Republik Indonesia [5] it can be seen that these cases have been processed and the cases have been decided by the court and have permanent legal force, including AKR (initial) with decision number 3617/Pid.Sus/2018/PN Mdn. He was found guilty with a prison sentence of 1 (one) year and a fine of $\mathrm{Rp}$.
$10,000,000$ (ten million rupiahs) provided that if the fine was not paid, it was replaced with imprisonment for 1 (one) month. AKR was found guilty of committing hate speech through social media Instagram stories (instastory) aimed at causing hatred or hostility to certain individuals and/or community groups based on ethnicity, religion, race, and intergroup (SARA) by insulting the flag of monotheism; JIT with decision number 931/Pid.Sus/2019/PN.Mdn. She was found guilty of imprisonment for 1 (one) year and 4 (four) months. JIT was found guilty of committing hate speech containing elements of blasphemy against Islam through her Facebook after losing two gallons of mineral water in front of her house; RAS with decision number 635/Pid.Sus/2018/PN Btm. She was found guilty by imprisonment for 6 (six) months and a fine of Rp. $10,000,000.00$ (ten million rupiahs) provided that if the fine was not paid, it was replaced with imprisonment for 2 (two) months. RAS was found guilty of committing hate speech containing elements of blasphemy against Islam through social media Facebook after the bombing of three churches in Surabaya. JM with decision number 949/Pid.Sus/2020/PN.Jkt.Utr. He was found guilty and sentenced to 3 (three) years in prison by the North Jakarta District Court. JM was found guilty of committing hate speech containing elements of SARA through his Facebook comment column; LL with decision number 1145/Pid.Sus/2020/PN Jkt.Utr. He was found guilty with a sentence of 1 (one) year and 10 (ten) months and a fine of Rp. 1,000,000,000.- (one billion rupiah), provided that if the fine was not paid, the fine was replaced with imprisonment for 3 (three) months. . LL was found guilty of blasphemy against Buddhism through social media YouTube and Facebook.

From the several cases of blasphemy above, the researcher chose one case that was taken from the results of the Medan District Court decision number 931/Pid.Sus/2019/PN.Mdn, namely the case that happened to JIT who was found guilty of committing hate speech containing elements of blasphemy. It happened after losing two gallons of mineral water in front of her house. The choice of data sources was because the news in the online mass media at that time was quite a lot and attracted public attention.

\section{METHOD}

The research method used in this study is qualitative with a forensic linguistic approach. A qualitative perspective is used because this research is directed at interpreting phenomena related to hate speech that contains elements of blasphemy against certain individuals and/or community groups. Meanwhile, the forensic linguistics approach is used because, in this study, text (utterance) in social media such as Facebook is not fully viewed as a sentence structure (syntax), but also as a process of social interaction that has legal 
implications. Therefore, the legal element in this study becomes the basis that functions as the context behind legal events, while linguistics is an analytical tool used to analyze data in this study. The theory that the writer uses in this research is the speech act theory introduced by Austin [6] and developed by Searle [7] and the appraisal system theory proposed by Martin \& White [8].

\section{FINDINGS AND DISCUSSION}

The following is data taken from the decision of the Medan District Court with decision number 931/Pid.Sus/2019/PN.Mdn. The data is lingual data written by JIT (initial) on her Facebook with the following words: "Anjing anjing sial $x w$ pny tetangga islam di kampung multatuli sini masa kt modi tukang air isi ulang ktY 2 galon kami udah dianter pas mlm itu jg tp buktiY engga ada pst ada yg iri siring samaku pa kt ustad ma di alquran di agama islam di ajarkn mencuri barang org di dpn rmh org klo itu bnr di agama islam di ajarkn ky gt q sumpahin demi nm tuhanku yg ambl 2 galonku di dpn rmhku hdpY seumr hdp jd miskin ga bkl dpt rejeki seumr hdp klrgY bkl sengsara seumur hdp. Islam ky tai babi sm klian pantesan rata2 org islam di kampung multatuli ini kebanyakan tukang pencuri hdpY slalu miskin slalu brkekurangan mkY mencuri 2 galon pnyku di dpn rmhku klo mnx udah miskin hdpY y miskin j ga ush pk ngmbl barang org yg bkn milikY mnx org islam di sini tanganY tangan panjang pencuri barang org ga malu y jd org islam maling ngmbl barang org pa lg ngakuY org islam taat sholat mdgn j ga ush ngaku2 org islam sebut $j$ islam ktp ko maling ngmbl 2 galon pnyku di dpn rmhku".

"What a bitch, I have Muslim neighbours in the multatuli village here. Modi (the refill water handyman) said that 2 gallons were delivered that night, but the 2 gallons was not there. There must be someone jealous of me. The Ustad says in the Koran about Islam, it is taught to steal people's things in front of their's homes if that's true in Islam. I swear in the name of my God, who took my 2 gallons in front of my house, her whole life being poor and will not get the fortune, her whole family will be miserable. Islam is like pig shit to you. No wonder that the average Muslim in this Multatuli village is mostly thieves, whose life is always poor, so steal my 2 gallons in front of my house. Muslims here are thieves. Take people's things, are you not ashamed to be a Muslim, steal people's things, what else do you claim to be a devout Muslim, it's better not to pretend to be a Muslim, let's say Islam just in their identity cards (KTP), thief 2 gallons of mine in front of my house"

The context of the JIT case began on Monday, July $30^{\text {th }}, 2018$ or at least sometime in July 2018, at the home of the defendant JIT in Medan City. The defendant was irritated and angry with a neighbour Mrs W. because at that time the defendant had lost two gallons of refillable drinking water from the front porch of her house and she suspected that it was Mrs W, who had taken it and then the defendant was noisy or had a fight with her husband about this, which caused the defendant to become emotional and angry, then the defendant opened her Facebook and then made a post.

\subsection{Analysis of Speech Acts}

Based on speech acts theory, when referring to the concept of speech act theory introduced by Austin [6], we will understand that when someone uses language (utterance) then basically he is doing an action (act). Therefore, in pragmatics, speech is always seen as an active dimension. Bachari [9] says that when speech is said to be an action, then the speech is never value-free because the speech is designed to achieve certain goals or purposes by the speaker. Austin [6] divided speech acts into three, namely; (a) locutionary act, (b) illocutionary act, and (c) perlocutionary act.

\subsubsection{Locutionary Acts}

Locutionary acts are the acts of speaking with words, phrases, and sentences according to the meanings contained by those words, phrases, sentences. This sentence can be called the act of saying something [10]. In this research, several utterances that become legal problems are taken from the locutionary acts in the lingual data of the JIT defendant: "Anjing anjing sial $x$ $w$ pny tetangga islam di kampung multatuli sini" dan "Islam ky tai babi sm klian pantesan rata2 org islam di kampung multatuli ini kebanyakan tukang pencuri hdpY slalu miskin slalu brkekurangan". "What a bitch, I have a Muslim neighbour in the multatuli village here" and "Islam is like pig shit to you. No wonder that the average Muslim in this Multatuli village is mostly thieves, whose life is always poor and lacking".

\subsubsection{Illocutionary Acts}

Based on the context, the speech act committed by the defendant JIT is an expressive speech act to insult and criticize through hate speech or insults to people or groups of Islamic society by using the following word: Islam ky tai babi (Islam is like pig shit), Anjing anjing sial $x w$ pny tetangga islam di kampung multatuli sini (What a bitch, I have a Muslim neighbors in the multatuli village here), and pantesan rata2 org islam di kampung multatuli ini kebanyakan tukang pencuri (No wonder that the average Muslim in this Multatuli village is mostly thieves).

\subsubsection{Perlocutionary Acts}

Perlocutionary acts of the utterances of the defendant JIT are (1) to make individuals or groups of Muslims feel dislike, hate, and create hostility; (2) hurt 
the heart and feelings of Muslims; (3) cause people reported JIT to the Medan Police of North Sumatra.

\subsection{Analysis of Appraisal System}

Based on the analysis of the appraisal system, the hate speech against Islam by the JIT defendant was proven from the use of language which was reflected in her language attitudes. From the utterance conveyed by the defendant JIT through her Facebook status, she has conveyed a judgment against a person or group of Islam by saying "Islam ky tai babi" (Islam is like a pig shit) and "pantesan rata2 org islam di kampung multatuli ini kebanyakan tukang pencuri". (No wonder that the average Muslim in this Multatuli village is mostly thieves). This assessment is negative because it can insult Islam and demean people who are Muslim. Therefore, the utterance conveyed by the defendant through her Facebook wall is an act that offended the law because the utterance is considered an act that hurts feelings.

\subsection{Analysis The Elements of Article 28 paragraph (2) of Law No.19 of 2016 on ITE}

\subsubsection{Element of everyone}

The Element of everyone means that criminal responsibility for the perpetrators of the crime of hate speech containing elements of SARA is carried out individually and not as a legal entity. A person who can be charged with a crime of hate speech containing elements of SARA is a person who can take responsibility, namely: mature and sane.

\subsubsection{Element of intentionally}

The element of intentionally means that the act of the JIT defendant who uploaded the status on her Facebook wall was carried out with full awareness and without any element of coercion from other parties.

\subsubsection{Element of disseminating information}

The element of disseminating information means that the JIT defendant has taken actions to spread information or hate speech that contains elements of blasphemy through her electronic media and social media Facebook so that the information can be accessed and known by many people (the public).

\subsubsection{Element of generating hatred or hostility to certain individuals and/or groups of people}

The element of generating hatred or hostility to certain individuals and/or groups of people means that something can arise, in this context referring to feelings of hatred or hostility to certain individuals/groups of society. The hatred (discomfort) or hostility (unfriendly) felt by certain individuals and/or community groups refers to the actions of the JIT defendants who intentionally and without rights have spread information, namely hate speech that contains elements of blasphemy against certain religions.

\subsubsection{Element based on ethnicity, religion, race, and intergroup (SARA)}

The element of based on ethnicity, religion, race, and intergroup (SARA) means that in Indonesian society there are certain groups of people formed based on similarities in ethnicity, religion, race, and intergroup. Community groups based on ethnicity are human groups whose members are based on the same lineage, language, customs, and arts. Such as Javanese, Sundanese, Batak ethnic groups, and so on. Community groups based on race are groups of people based on similarities in physical and biological characteristics, as well as geographic origins such as Mongoloid, Negroid, and so on. Community groups based on religious similarity are community groups based on the similarity of the beliefs they profess, such as Muslim, Christian, Catholic, Hindu and Buddhist. Community groups based on intergroup are groups of people who identify themselves because of similar interests, occupations, ideologies or political views, such as working-class community, community groups supporting reform, community groups supporting Jokowi and so on.

Base on the analysis of the elements in Article 28 paragraph (2) of the Law No.19 of 2016 on ITE [4] has been fulfilled, then the judge of Medan District Court has determined JIT through decision number 931/Pid.Sus/2019/PN.Mdn guilty of committing a crime without rights or against the law for spreading information aimed at causing hatred or hostility towards certain individuals or groups of people based on SARA with a prison sentence of 1 (one) year and 4 (four) months.

\section{CONCLUSION}

Based on data analysis, the results of this research are expressive speech acts carried out by the JIT defendant contains utterances of hatred or contempt for Islam and based on the analysis of the appraisal system, hate speech against Islam by the JIT defendant was proven from the use of language which was reflected in her language attitude, namely negative judgment of people or groups of Islam where these things can insult religion and demean people who are Muslims. The legal impact of the utterance of the defendant JIT is that the Medan District Court judge sentenced the defendant JIT to a prison sentence of 1 (one) year and 4 (four) months. This is following Article 28 paragraph (2) Jo. Article 
45A paragraph (2) of Law No.19 of 2016 about the changes of Law Number 11 of 2008 on ITE. The results of this research are expected to be used as a source of knowledge by the people interacting on social media. The public should pay attention to good, polite, and courteous communication etiquette on social media to avoid legal problems caused by the utterances.

\section{ACKNOWLEDGMENTS}

This article is a part of the author's (Agus Syahid) dissertation research which was promoted by Dadang Sudana and Andika Dutha Bachari. The author is grateful for the support of Beasiswa Pendidikan Pascasarjana Dalam Negeri (BPP-DN).

\section{REFERENCES}

[1] Moeljatno. (2015). Asas Asas Hukum Pidana, cetakan IX. Jakarta: Rineka Cipta.

[2] Kamus Besar Bahasa Indonesia (KBBI) online. (2021). Retrieved April $25^{\text {th }}, 2021$, at 09.34 a.m.

[3] Bachari, A. D. (2020). Pembuktian Pidana Penyebaran Berita Bohong dalam Sistem Peradilan Pidana di Indonesia. Jurnal Membaca, 5(November), 93-104.

[4] Undang-Undang Informasi dan Transaksi Elektronik. (2016). No.19 Tahun 2016 perubahan atas UU No.11 Tahun 2008 tentang ITE.

[5] Direktori Putusan Mahkamah Agung Republik Indonesia. (2021). Retrieved March $3^{\text {th }}$, 2021, at 9:32 p.m.

[6] Austin, J. L. (1962). How do to Things with Words. Cambridge: Harvard University Press.

[7] Searle, J. R. (1969). Speech Acts. An Essay in the Philosophy of Language. Oxford: Cambridge University Press.

[8] Martin, J. R., \& White, P. R. . (2005). The Language of evaluation: Appraisal in English. In Discourse and Writing/Rédactologie. New York: Palgrave Macmillian.

[9] Bachari, A. D. (2010). Analisis Pragmatik terhadap Tindak Tutur yang Berdampak Hukum. Jurnal KIMLI.

[10] Rahardi, K. (2005). Pragmatik: Kesantunan Imperatif Bahasa Indonesia. Jakarta: Erlangga. 